\title{
REGULARITIES OF FORMING THE STRUCTURAL STRENGTH OF VACUUM CONCRETE WHEN COMPACTING CONCRETE MIXES
}

\author{
${ }^{1}$ Storozhuk M.A., Doctor of Engineering, Professor, \\ storozhukpsacea@gmail.com, ORCID 0000-0002-3132-8864 \\ ${ }^{1}$ Pavlenko T.M., PhD, Assistant Professor, \\ tmj@ukr.net, ORCID 0000-0003-4325-7562 \\ ${ }^{1}$ Abbasova A.R. \\ abbasova003@gmail.com, ORCID 0000-0001-9643-5305 \\ ${ }^{1}$ SHEE «Prydniprovska State Academy of Civil Engineering and Architecture» \\ Chernyshevsky str., 24a, Dnipro, 49600, Ukraine
}

\begin{abstract}
The paper presents the results of theoretical and experimental studies of structural strength and strength at the age of 28 days of vibrovacuumized and vibrated concrete. Structural strength is very important when moulding prefabricated or monolithic structures with immediate dismantling.

Regularities of removal of a part of tempering water (liquid phase) from vibrovacuumized concrete mix, having capillaries of various form (round, square, formed by three or four cylinders), narrowing and expanding capillaries, and also capillaries of variable cross-section (with areas that expand and contract), are established as a result of researches. In such capillaries, the value of the capillary pressure is different and, accordingly, at different values of the external pressure, the liquid phase is removed. Also the value of breakdown pressure at which the liquid phase is removed from capillaries of variable section and with sites of small diameter is calculated.

The high structural strength of vacuum concrete is theoretically substantiated. The results of experimental studies confirmed the theoretical developments and showed that the structural strength of freshly moulded vacuum concrete is $7 \ldots 8$ times greater than that of vibrated concrete from rigid concrete mix at the same W/C ratio, almost the same cement consumption and density. This significantly affects the strength of concrete substantiated with immediate dismantling.

Due to the high structural strength, vacuum concretes do not show a decrease in strength at the age of 28 days during the moulding of structures with immediate dismantling compared to concretes, the dismantling of which was made in a day after moulding. Vibrated concretes from rigid concrete mix have such decrease in durability in the range $12 \ldots 15 \%$. These data indicate the advantages of vibrovacuumized concrete over vibrated concrete from rigid concrete mix.
\end{abstract}

Keywords: vacuum concrete, capillary pressure, moulding, immediate dismantling, vibrovacuumizing, structural strength.

Introduction. Vibrovacuumizing of concrete mixes allows moulding structures with partial or complete immediate dismantling, accelerating the concrete hardening, increasing its strength and other properties. At the same time, the most important indicator of vacuum treatment of concrete mixes, on which the properties depend, is the structural strength of vacuum concrete (the strength of freshly moulded concrete). It is necessary to know and take into account the laws of removing the excess tempering water from pores and capillaries of different shapes and the degree of compaction of the concrete mix during vacuumizing to achieve its maximum possible value.

Analysis of publications. When using vibrovacuumizing as one of the methods of compaction of concrete mixes at moulding concrete and reinforced concrete structures, it is possible to remove excess tempering water from the concrete mix and thereby significantly increase the physical and mechanical properties of concrete or reinforced concrete [1]. Studies have shown that even with optimal moulding control, the vacuum coefficient $\left(\mathrm{k}_{\text {vac. }}\right)$ is less than one [2]:

$$
\mathrm{k}_{\text {vac. }}=\left(V_{c . m .}^{b}-V_{c . m .}^{a}\right) / W_{\text {ext. }},
$$


where $V_{c . m .}^{b}, V_{c . m .}^{a}$ - respectively the volume of the concrete mix before and after vibrovacuumizing;

$W_{\text {ext. }}$ - the amount of water extracted during vibrovacuumizing.

With this $\mathrm{k}_{v a c}$, not all the pore space of the compacted concrete mix is filled with the liquid phase - part of the capillary (s) is filled with the liquid, and part with the gaseous phase.

These conditions are explained as follows. The tempering water (liquid phase) located in the pores of the compacted concrete mix has a very complex free surface. This is due to the pore space, which is characterized by the most incredible outlines. Capillary forces bend the surface of the liquid phase and create favorable conditions for the occurrence of capillary pressure of different values, depending on the type, shape and size of the capillary. Therefore, knowing the localization of the menisci and their form in a variety of capillaries of the concrete mix is very important to ensure maximum structural strength of vacuum concrete immediately after moulding of the structure.

In order to remove the liquid phase from the capillaries of the compacted concrete mix, it is necessary to overcome the capillary pressure, which depends on the surface tension, the wetting angle, the radius of the capillary and its shape. The simplest solution is for a round capillary, where the meniscus has a spherical shape, and the capillary pressure is expressed by the dependence [3]:

$$
\mathrm{P}_{\mathrm{c}}=(2 \sigma \cos \theta) / r \text {, }
$$

where $\mathrm{P}_{\mathrm{c}}$ - capillary pressure;

$\sigma$ - surface tension;

$\theta$ - wetting angle;

$r$ - the radius of the capillary.

In a round capillary, the gaseous phase and the liquid phase are sharply separated. On one side of the meniscus, the capillary is completely filled with the liquid phase, and on the other - with the gaseous phase.

Purpose of the work. To study and justify the conditions for obtaining high structural strength of vacuum concrete, to determine its effect on the strength and other properties of concrete.

Materials and methods of research. First a freeform capillary was considered. In such a capillary, the part filled with the gaseous phase may contain a certain amount of the liquid phase located in the sharp corners of the capillary. In this case, a kind of liquid "whiskers" is formed, which gradually passes into the meniscus [3,4]. In that event, it is possible to find the capillary pressure based on such considerations.

Let the created pressure difference displace the liquid phase from the capillary of the concrete mix, thus forming additional surfaces of the "solid phase - gaseous phase" and "liquid phase - gaseous phase", and the "solid phase - liquid phase" surface decreases. In this case, the surface energy in the compacted concrete mix increases.

From this condition, the patterns of changes in capillary pressure in the compacted concrete mix can be found. Let the meniscus move a distance $\Delta x$ under the influence of the pressure difference P. The gaseous phase will complete the work:

$$
\mathrm{A}=\mathrm{P} \cdot \mathrm{S}_{g} \cdot \Delta x
$$

$\mathrm{S}_{g}$ - the cross-sectional area of the capillary (away from the meniscus) filled with the gaseous phase.

Liquid "whiskers" cause this area to differ from the cross-sectional area of the entire capillary. The perimeter that limits the gaseous phase in this section separates it from the solid phase in some places, and from the liquid phase in others. The lengths of the corresponding sections are denoted by $l_{\mathrm{sg}}$ and $l_{\mathrm{lg}}$. The resulting surface energy is equal to:

$$
G_{s}=\left[\sigma l_{\mathrm{lg}}+\left(\sigma_{s g}-\sigma_{s l}\right) l_{s g}\right] \Delta x .
$$

If the movement of the meniscus was reversible and isothermic, then the change in free surface energy is equal to the work expended. Then the general regularities of changes in capillary pressure in capillaries of arbitrary cross-section will be:

$$
P_{c}=\left[\sigma l_{\mathrm{lg}}+\left(\sigma_{s g}-\sigma_{s l}\right) l_{s g}\right] / S_{g}=\sigma\left(l_{\mathrm{lg}}+l_{s g} \cdot \cos \theta\right) / S_{g} .
$$


Next, a specific type of capillary - a capillary of square cross-section with a side of size $a$ will be considered.

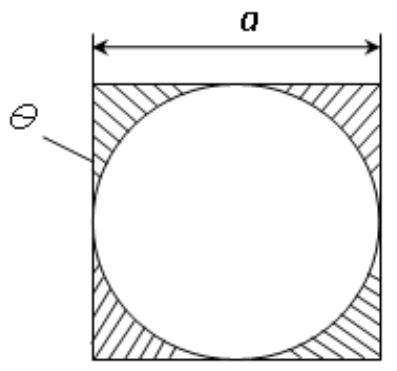

Fig. 1. Regularities of liquid phase removal from a square-section capillary

Fig. 1 shows the cross-section of such a capillary away from the meniscus. The cross-section of the liquid "whiskers" is shaded. The free surface of the "whiskers" is cylindrical. The radii of curvature of the meniscus $R_{1}=\sigma / P_{c}$ and $R_{2}=\infty$. The intersection of the free surface of the "whiskers" with the walls of the capillary passes at an angle $\theta$. Based on this, and taking into account the work [5], the dependence is obtained for the length of the boundary between the liquid and gaseous phases:

$$
l_{\mathrm{lg}}=8 \sigma(\pi / 4-\theta) / P_{c} .
$$

From this dependence, it follows that the "whiskers" can only exist under the condition $\theta<\pi / 4$. Under this condition, a concave arc at an angle $\theta$ can be entered in the corner of the square.

Further, taking into account the work [5], we find:

$$
\begin{aligned}
& l_{s g}=8 a-8 \sqrt{2} \sigma / P_{c} \sin (\pi / 4-\theta), \\
& S_{g}=a^{2}-4 \sigma^{2} / P_{c}^{2}\left(\cos ^{2} \theta-\sin \theta \cos \theta-\pi / 4+\theta\right) .
\end{aligned}
$$

Substituting dependencies (4) and (5) into equation (2) and solving it with respect to $\mathrm{P}_{c}$ and taking into account the results of research [6], the capillary pressure in a square capillary can be found:

$$
P_{c}=2 \sigma / a(\cos \theta+\sqrt{\pi / 4-\theta+\sin \theta \cos \theta}) \text {. }
$$

If $\pi / 2>\theta>\pi / 4$, then "whiskers" are not formed and from equality (6) we get:

$$
P_{c}=(4 \sigma \cos \theta) / a \text {. }
$$

Thus, all other things being equal, the capillary pressure in a square capillary is 2 times greater than in a round capillary. Therefore, when vacuuming the concrete mix in this case, a large pressure difference at the ends of the capillary is necessary to remove the liquid phase.

For practical applications, another type of capillaries is very important, which in a simplified form is the space between three parallel cylinders of radius $R$. The cross-section of such a capillary is shown in Fig. 2. Such a cross-section of the capillary is very common in the study of porous materials and, in particular, compacted concrete mixes.

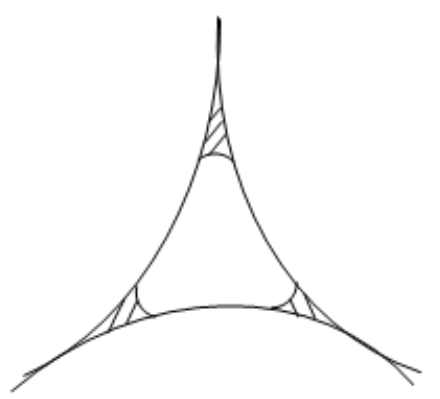

Fig. 2. Regularities of liquid phase removal from a capillary formed by three cylinders of radius $R$ 
When vacuumizing the concrete mix in the corners of such a capillary, the liquid phase is retained under any conditions. Unfortunately, the analytical dependence for capillary pressure in this case has not yet been obtained. Fig. 3 shows the experimental dependence of the capillary pressure expressed in units $\sigma / R$ on the wetting angle for the capillary under consideration [4]. From this relationship, it can be seen that with an increase in the wetting angle, the capillary pressure in such capillaries decreases sharply.

If the cylinders forming the capillary are located at a certain distance from each other (Fig. 4), then other regularities are observed when the liquid phase is removed.

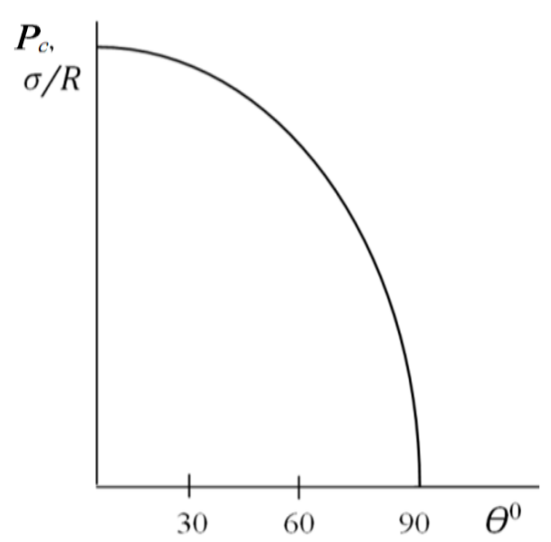

Fig. 3. Dependence of capillary pressure in a capillary formed by three cylinders on the wetting angle

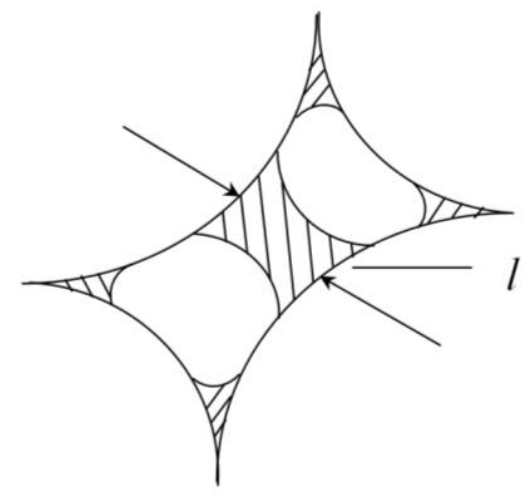

Fig. 4. Regularities of liquid phase removal from a capillary formed by four cylinders of radius $R$

It should be noted that this configuration of the capillary is also most likely in the compacted concrete mix and is completely determined by the radius of the cylinders $R$, as well as the width of the capillary $l$ in the middle part. When the liquid phase is removed, the "whiskers" may remain not only in the corners of the capillary, but also in its middle part, if the value of $l$ is small enough. In this case, the gaseous phase is separated by a bridge from the liquid phase into two separate sections. If $l$ is large enough, then there will be no such bridge in the middle part of the capillary and the gaseous phase will occupy the entire space, except for the corners, when vacuumizing the concrete mix.

In compacted concrete mix, there are always capillaries of variable cross-section in addition to the capillaries considered. In order to simplify the process, first the laws of liquid phase movement in expanding and narrowing circular capillaries will be considered. Let the capillary be narrowing if the bulge of the meniscus of the liquid phase is directed towards narrowing (Fig. 5, a), and expanding towards the expansion of the capillary (Fig. 5, b).

a)

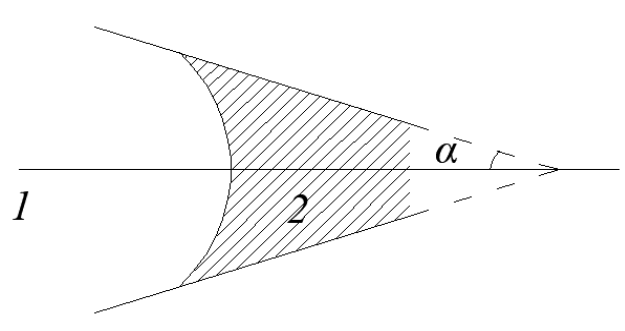

b)

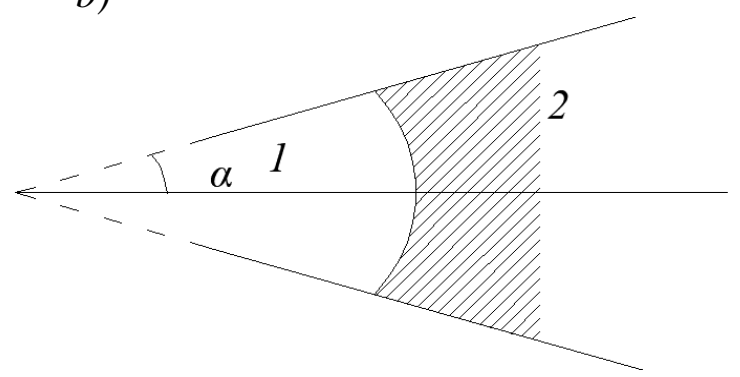

Fig. 5. Liquid and gaseous phases in narrowing (a) and expanding (b) capillaries:

1 - gaseous phase; 2 - liquid phase

If the cross-section of the capillary is circular with a radius $r$ at the location of the meniscus, then in a narrowing capillary, the capillary pressure is:

$$
P_{c}=2 \sigma_{\mathrm{lg}} \cos (\theta-\alpha) / r \text {. }
$$


Accordingly, in an expanding capillary, it will be:

$$
P_{c}=2 \sigma_{\mathrm{lg}} \cos (\theta+\alpha) / r .
$$

In an expanding capillary, the meniscus is not stable. Indeed, let the meniscus be in a state of equilibrium in any position. This is possible if the capillary pressure $P_{c}$ balances the external pressure (more precisely, the pressure difference at the ends of the capillary). If the external pressure is increased, the meniscus will move to a wider part of the capillary (Fig. 5, b). In this case, the capillary pressure will decrease; therefore, it will no longer be able to balance the external pressure. As a result, the gaseous phase will completely displace the liquid phase from the expanding capillary. For the same reason, a decrease in external pressure should cause the liquid phase to move towards the narrow part, until the entire capillary volume is completely filled. In contrast, in the narrowing capillary meniscus stable, since the movement of the liquid phase with increasing external pressure is accompanied by a decrease of the radius of curvature of the meniscus and as a consequence - increase in capillary pressure.

Be aware that in most cases in the capillaries of the compacted concrete mix there are some narrowing and widening sections (Fig. 6). To move the liquid phase in these capillaries it is necessary to determine the breakdown pressure $P_{b r}$ required for complete displacement of the liquid phase from the narrowing part in the expanding capillary. In this case, it is necessary to overcome the maximum capillary pressure $\left(P_{c}\right)_{\max }$ equal to $P_{b r}$, which corresponds to the meniscus with the minimum radius of curvature $R_{\min }$.
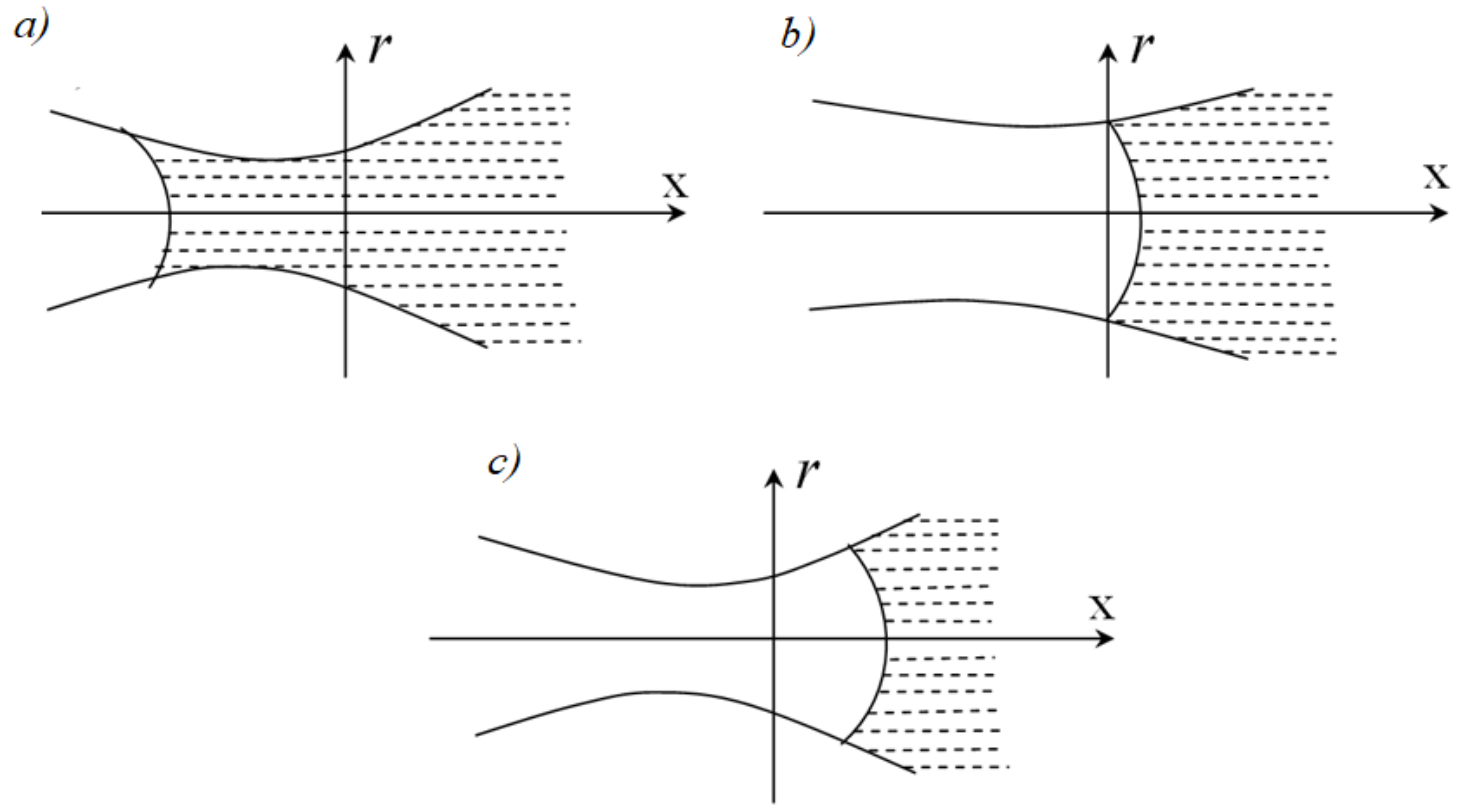

Fig. 6. Variants of the location of the meniscus of the liquid (liquid phase) in a capillary of variable cross-section:

$\mathrm{a}$ - in the narrowing part of the capillary; $\mathrm{b}$ - in the narrowest part of the capillary; $\mathrm{c}-$ in the expanding part of the capillary

As is known [7, 8], the capillary section which is described by the function $r=r(x)$, the curvature of the meniscus is determined by the relationship:

$$
1 / R=(\cos \theta+d r / d x \sin \theta) / r \sqrt{1+(d r / d x)^{2}} .
$$

For the origin made the narrowest part - the neck of the capillary (Fig. 6). It is assumed that the cross-section of the capillary on both sides of the constriction is an arc of a circle with radius $R_{o}$.

Then:

$$
\left.1 / R=\left\lfloor\sqrt{R_{o}^{2}-x^{2}} \cos \theta+x \sin \theta\right\rfloor / \mid b+R_{o}-\sqrt{R_{o}^{2}-x^{2}}\right\rfloor,
$$

where $b$ - the radius of the capillary neck. 
This ratio allows determining the breakdown pressure in two extreme cases.

The radius of rounding at the transition from the neck to the expanding part is very small $\left(R_{o}<<b\right)$. Then:

$$
1 / R=\left\lfloor\sqrt{R_{o}^{2}-x^{2}} \cos \theta+x \sin \theta\right\rfloor / R_{o} b .
$$

The maximum curvature of the meniscus is reached at $x=R_{o} \cdot \sin \theta$ and is equal to $1 / b[9,10]$. Therefore, to bring the meniscus to the neck, it is necessary to create pressure $P=2 \sigma_{\mathrm{lg}} \cos \theta / b$, and to completely displace the liquid phase from the sharply expanding capillary, you need a higher pressure $\left(P_{b r}\right)$ :

$$
P_{b r}=2 \sigma_{\mathrm{lg}} / b .
$$

From the above, it is obvious that a material, which solid phase consists of tiny particles, and the pore space between them is filled with liquid, during the formation of menisci and, accordingly, the occurrence of capillary pressure, the latter has a significant effect on the adhesion (convergence) of solid phase particles. Due to this, the material acquires greater structural strength. This fully applies to the concrete mix compacted by vacuumizing. In this case, due to the removal of part of the tempering water, menisci of different curvature are formed depending on the type, shape and size of the capillary, capillary pressure occurs, which contributes to the compression of solid phase particles by the liquid phase, which ensures high structural strength of freshly moulded vacuum concrete and further improvement of its properties over time in comparison with vibrated concrete, in which capillary pressure is practically absent immediately after moulding. Such regularities in freshly moulded vacuum concrete are clearly demonstrated on two parallel plates, between which there is a liquid layer of very small thickness (Fig. 7) [11].
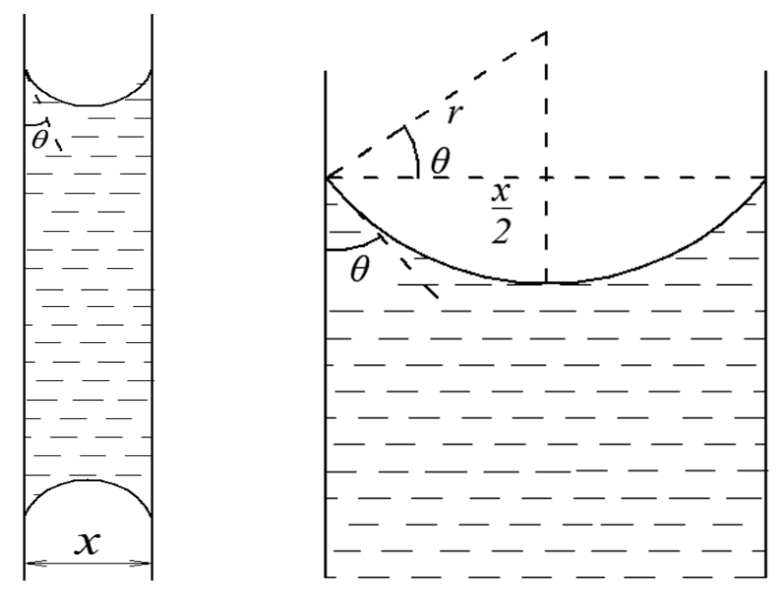

Fig. 7. The phenomenon of capillarity between two parallel plates

Along the perimeter of the plates, the liquid comes into contact with air (the environment), so the meniscus of the liquid is concave and the pressure inside the liquid is less than the air pressure; as a result, the atmospheric pressure acting on the plates tends to bring them closer, so they will be attracted to each other. If the distance between the plates is small enough, the meniscus of the fluid can be considered as part of a cylindrical surface of some radius $r$. This radius is related to the distance $x$ between the plates by the equation:

$$
x=2 r \cos \theta .
$$

Based on this, the "lack" of pressure in the liquid that is located between the plates is equal to:

$$
P_{c a v}=2 \sigma \cos \theta / x \text {. }
$$

The force of mutual attraction of the plates $F$ is determined by multiplying this value by the area of contact of the liquid with the plates $S_{p}$ :

$$
F=2 \sigma S_{p} \cos \theta / x
$$


This force is inversely proportional to the distance between the plates. At small distances, it can reach large values - the plates are pressed together with a pressure of about $0.15 \ldots 0.2 \mathrm{MPa}$ [11]. Experimental data on the effect of capillary pressure on the structural strength of vacuum concretes are presented below.

Results of experimental studies. The following materials were used in carrying out these studies:

- Portland cement M400 (Krivoy Rog);

- Dnipro sand, $\mathrm{M}_{\text {size }}=1.52$;

- crushed granite, 10...20 mm fractions (Dnipro, Rybalsky quarry).

The strength of concrete was determined on samples $150 \times 150 \times 70 \mathrm{~mm}$, which were tested «edgewise» (to reduce the influence of the scale factor). When moulding samples duration of vacuum processing at vacuum 0.7 (absolute vacuum is taken for unity) was $6 \mathrm{~min}$. In order to destroy directed capillaries and free formations during vacuumizing, short-term periodic vibration was performed ( $5 \ldots 10 \mathrm{~s}$ every $2 \mathrm{~min}$ ). For comparison, a rigid mix was prepared from a concrete mix of the same composition, from which the same samples were moulded with a load of $0.006 \mathrm{MPa}$, using vibration during $55 \ldots 60 \mathrm{~s}$.

The test results showed (Table 1) that the structural strength of freshly moulded vacuum concrete is $7 . . .8$ times greater than that of vibrated concrete from a rigid concrete mix at the same W/C ratio, almost the same cement consumption and density. Thus, in our experiments, the structural strength of freshly moulded vacuum concrete was $0.24 \ldots 0.37 \mathrm{MPa}$, and that of vibrated concrete from rigid concrete mix was $0.03 \ldots 0.05 \mathrm{MPa}$. This is the most important feature of vacuum concrete. In concrete from a rigid mix, structural strength is provided by the adhesion of solid phase particles and vandervaals forces, which are characterized by a very small value. In vacuum concrete, high structural strength is achieved by capillary compression of the solid phase by the liquid phase, i.e. by straining the tempering water in the capillaries.

Table 1 - Density and structural strength of concrete depending on its composition and compaction method

\begin{tabular}{|l|c|c|c|c|c|c|}
\hline \multirow{2}{*}{$\begin{array}{c}\text { Concrete } \\
\text { composition }\end{array}$} & \multicolumn{2}{|c|}{ W/C ratio of concrete } & \multicolumn{2}{c|}{ Density, $\mathrm{kg} / \mathrm{m}^{3}$} & \multicolumn{2}{c|}{ Structural strength, MPa } \\
\cline { 2 - 6 } & vibrated & $\begin{array}{c}\text { vibrovacuu } \\
\text { mized }\end{array}$ & vibrated & $\begin{array}{c}\text { vibrovacuu } \\
\text { mized }\end{array}$ & vibrated & $\begin{array}{c}\text { vibrovacuu } \\
\text { mized }\end{array}$ \\
\hline $1: 1.2: 2.8$ & 0.33 & 0.33 & 2464 & 2471 & 0.033 & 0.24 \\
\hline $1: 2.2: 3.8$ & 0.44 & 0.44 & 2439 & 2448 & 0.040 & 0.28 \\
\hline $1: 2.58: 4.52$ & 0.52 & 0.52 & 2394 & 2410 & 0.050 & 0.37 \\
\hline $1: 3.6: 5.4$ & 0.56 & 0.56 & 2375 & 2452 & 0.041 & 0.32 \\
\hline
\end{tabular}

Such high strength of freshly moulded vacuum concrete according to R. Lermit allows building structures up to $6 \mathrm{~m}$ high with immediate dismantling [12].

It is natural to assume that the immediate dismantling of moulded structures will have some effect on the strength of concrete at the age of 28 days. When testing this assumption, the materials for preparing the concrete mix, the moulding modes, and the sample sizes are assumed to be the same as in previous experiments.

At the same time, a batch of vibrated and vibrovacuumized samples was moulded, and then dismantled in a day after moulding. All samples hardened for 28 days under normal conditions. The results of the experiments are shown in Table 2.

Vibrated samples from rigid concrete mix with immediate dismantling have strength lower by $12 \ldots 15 \%$ in comparison with the strength of the same samples, but dismantled in a day after molding. This decrease in the strength of vibrated concretes moulded with immediate dismantling is explained by the partial destruction of their structure during the initial period of hardening under the influence of gravitational forces due to insufficient compression by capillary forces of the solid phase. 
Vibrovacuumized concrete moulded with immediate dismantling does not show a decrease in strength in comparison with the strength of concrete samples dismantled in a day after moulding. In addition, it should be noted that the strength of vibrovacuumized concrete was $15 . .20 \%$ higher, compared with the strength of vibrated concrete from a rigid concrete mix.

Table 2 - Density of freshly moulded concrete and strength in 28-day age of vibrovacuumized and vibrated concrete

\begin{tabular}{|l|c|c|c|c|c|}
\hline \multirow{2}{*}{ Type of concrete } & $\begin{array}{c}\text { Concrete } \\
\text { composition }\end{array}$ & $\begin{array}{c}\text { W/C } \\
\text { ratio of } \\
\text { concrete }\end{array}$ & Dismantling & $\begin{array}{c}\text { Density, } \\
\mathrm{kg} / \mathrm{m}^{3}\end{array}$ & $\begin{array}{c}\text { Ultimate } \\
\text { compression } \\
\text { strength, MPa }\end{array}$ \\
\hline \multirow{2}{*}{ Vibrovacuumized } & $1: 2.2: 3.8$ & 0.43 & $\begin{array}{c}\text { In a day after } \\
\text { moulding }\end{array}$ & 2452 & 38.7 \\
\cline { 2 - 6 } & $1: 2.2: 3.8$ & 0.43 & $\begin{array}{c}\text { Immediate } \\
\text { dismantling }\end{array}$ & 2448 & 39 \\
\cline { 2 - 6 } & $1: 2.2: 3.8$ & 0.43 & $\begin{array}{c}\text { In a day after } \\
\text { moulding }\end{array}$ & 2380 & 25.8 \\
\hline \multirow{2}{*}{ Vibrated } & $1: 2.2: 3.8$ & 0.43 & $\begin{array}{c}\text { Immediate } \\
\text { dismantling }\end{array}$ & 2373 & 22.6 \\
\cline { 2 - 6 } & $1: 1.9: 4.1$ & 0.43 & $\begin{array}{c}\text { Immediate } \\
\text { dismantling }\end{array}$ & 2386 & 24.1 \\
\hline
\end{tabular}

These data indicate the advantages of vibrovacuumized concrete over vibrated concrete from rigid concrete mix.

Conclusions. Regularities of removal of a part of tempering water (liquid phase) from vibrovacuumized concrete mix, having capillaries of various form (round, square, formed by three or four cylinders), narrowing and expanding capillaries, and also capillaries of variable cross-section (with areas that expand and contract), are established as a result of researches. In such capillaries, the value of the capillary pressure is different and, accordingly, at different values of the external pressure, the liquid phase is removed.

The value of breakdown pressure at which the liquid phase is removed from capillaries of variable section and with sites of small diameter is calculated.

The high structural strength of vacuum concrete is theoretically substantiated. The results of experimental studies confirmed the theoretical developments and showed that the structural strength of freshly moulded vacuum concrete is $7 \ldots 8$ times greater than that of vibrated concrete from rigid concrete mix at the same W/C ratio, almost the same cement consumption and density. This significantly affects the strength of concrete moulded with immediate dismantling.

Due to the high structural strength, vacuum concretes do not show a decrease in strength at the age of 28 days during the moulding of structures with immediate dismantling compared to concretes, the dismantling of which was made in a day after moulding. Vibrated concretes from rigid concrete mix have such decrease in durability in the range $12 \ldots 15 \%$.

\section{References}

[1] V.S. Zinchenko, Vibrovakuumnoye formirovaniye zhelezobetona: osnovy tekhnologii proizvodstva vysokoprochnykh i dolgovechnykh betonov. Dnepropetrovsk: Porogi, 2009.

[2] N.A. Storozhuk, Vibrovakuumirovaniye betonnykh smesey $i$ svoystva vakuumbetona. Dnepropetrovsk: Porogi, 2008.

[3] C. Ono, S. Kondo, Molekulyarnaya teoriya poverkhnostnogo natyazheniya $v$ zhidkostyakh. Moskva: Izdatel'stvo IL, 1963. 
[4] Yu.A. Chizmadzhev, V.S. Markin, M.R. Tarasevich, Yu.G. Chirkov, Makrokinetika protsessov v poristykh sredakh (Toplivnyye elementy). Moskva.: Nauka, 1971.

[5] J.T. Davies, E.K. Rideal, Interfacial Phenomena. Academic Press, 1963.

[6] N.K. Adam, Fizika i khimiya poverkhnostey. Moskva -Leningrad: Gostekhizdat, 1947.

[7] B.D. Summ, Yu.V. Goryunov, Fiziko-khimicheskiye osnovy smachivaniya i rastekaniya. Moskva: Khimiya, 1976.

[8] N.F. Bondarenko, S.V. Nerpin, "Sootnosheniye mezhdu sdvigom i prochnost'yu zhidkostey v ob"yeme i granichnykh sloyakh" $V \mathrm{kn}$. "Poverkhnostnyye sily $v$ tonkikh plenkakh i dispersnykh sistemakh”. Moskva, Nauka, 1972, pp. 281-289.

[9] E.K. Raydil, Khimiya poverkhnostnykh yavleniy. Leningrad: ONTI-Khimteoret, 1936.

[10] R. Kollinz, Techeniye zhidkostey cherez poristyye materialy. Moskva: Mir, 1964.

[11] L.D. Landau, A.I. Akhiyezer, Ye.M. Lifshits, Kurs obshchey fiziki. Mekhanika $i$ molekulyarnaya fizika. Moskva: Nauka, 1969.

[12] R. Lermit, Problemy tekhnologii betona. Moskva: Gosstroyizdat, 1959.

\title{
ЗАКОНОМІРНОСТІ ФОРМУВАННЯ СТРУКТУРНОЇ МІЦНОСТІ ВАКУУМБЕТОНУ ПРИ УЩІЛЬНЕННІ БЕТОННИХ СУМІШЕЙ
}

\author{
${ }^{1}$ Сторожук М.А., Д.Т.н., професор, \\ storozhukpsacea@gmail.com, ORCID 0000-0002-3132-8864 \\ ${ }^{1}$ Павленко Т.М., к.т.н., доцент, \\ tmj@ukr.net, ORCID 0000-0003-4325-7562 \\ ${ }^{1}$ Аббасова А.P., к.т.н., \\ abbasova003@gmail.com, ORCID 0000-0001-9643-5305 \\ ${ }^{1}$ ДВНЗ «Придніпровська державна академія будівництва та архітектури» \\ вул. Чернишевського, 24-а, м. Дніпро, 49600, Україна
}

Анотація. У роботі наведені результати теоретичних і експериментальних досліджень структурної міцності і міцності у 28-ми добовому віці вібровакуумованих і віброущільнених бетонів. Показники по структурній міцності є найважливішими при формуванні збірних або монолітних конструкцій з негайною розпалубкою.

В результаті виконання досліджень встановлені закономірності видалення частини води замішування (рідкої фази) з бетонної суміші, що ущільнюється вібровакуумуванням, 3 капілярів різної форми (круглих, квадратних, утворених трьома або чотирма циліндрами), 3 капілярів, що звужуються i розширюються, а також 3 капілярів змінного перерізу (3 ділянками, що розширюються і звужуються). У таких капілярах різна величина капілярного тиску i, відповідно, при різній величині зовнішнього тиску видаляється рідка фаза. Також розрахована величина тиску пробою, при якому видаляється рідка фаза 3 капілярів змінного перерізу і з дільницями малого діаметра.

Теоретично обгрунтована висока структурна міцність вакуумбетону. Результати експериментальних досліджень підтвердили теоретичні розробки і показали, що структурна міцність свіжовідформованого вакуумбетону в 7..8 разів більша, ніж у віброущільненого 3 жорсткої бетонної суміші при одному і тому ж В/Ц, практично однакових витратах цементу і щільності. Це істотно позначається на міцності бетонів, відформованих з негайною розпалубкою.

У вакуумбетонів із-за високої структурної міцності не спостерігається зниження міцності у віці 28 діб при формуванні конструкцій з негайною розпалубкою порівняно 3 бетонами, розпалубка яких виконувалася через добу після формування. У віброущільнених бетонів із жорсткої бетонної суміші таке зниження міцності складає $12 \ldots 15 \%$.

Наведені дані свідчать про переваги вібровакуумованого бетону перед віброущільненим 3 жорсткої бетонної суміші.

Ключові слова: вакуумбетон, капілярний тиск, формування, негайна розпалубка, вібровакуумування, структурна міцність. 


\title{
ЗАКОНОМЕРНОСТИ ФОРМИРОВАНИЯ СТРУКТУРНОЙ ПРОЧНОСТИ ВАКУУМБЕТОНА ПРИ УПЛОТНЕНИИ БЕТОННЫХ СМЕСЕЙ
}

\author{
${ }^{1}$ Сторожук Н. А., д.т.н., профессор, \\ storozhukpsacea@gmail.com, ORCID 0000-0002-3132-8864 \\ ${ }^{1}$ Павленко Т.М., к.Т.н., доцент, \\ tmj@ukr.net, ORCID 0000-0003-4325-7562 \\ ${ }^{1}$ Аббасова А.P., к.т.н., \\ abbasova003@gmail.com, ORCID 0000-0001-9643-5305 \\ ${ }^{1}$ ГВУЗ «Приднепровская государственная академия строительства и архитектуры» \\ ул. Чернышевского, 24-а, г. Днепр, 49600, Украина
}

\begin{abstract}
Аннотация. В работе приведены результаты теоретических и экспериментальных исследований структурной прочности и прочности в 28-ми суточном возрасте вибровакуумированных и виброуплотненных бетонов. Показатели структурной прочности являются важнейшими при формовании сборных или монолитных конструкций с немедленной распалубкой. $\mathrm{B}$ результате выполнения исследований установлены закономерности удаления части воды затворения (жидкой фазы) из уплотняемой вибровакуумированием бетонной смеси из капилляров разной формы (круглых, квадратных, образованных тремя или четырьмя цилиндрами), из капилляров, сужающихся и расширяющихся, переменного сечения (с участками расширяющимися и сужающимися). В таких капиллярах разная величина капиллярного давления и, соответственно, при различной разности внешнего давления удаляется жидкая фаза. Также рассчитана величина давления пробоя, при котором удаляется жидкая фаза из капилляров переменного сечения и с шейками малого диаметра. Теоретически обоснована высокая структурная прочность вакуумбетона. Результаты экспериментальных исследований подтвердили теоретические разработки и показали, что структурная прочность свежеотформованного вакуумбетона в 7...8 раз больше, чем у виброуплотненного из жесткой бетонной смеси при одном и том же В/Ц, практически одинаковых расходах цемента и плотности. Это существенно сказывается на прочности бетонов, отформованных с немедленной распалубкой. У вакуумбетонов из-за высокой структурной прочности не наблюдается снижения прочности в возрасте 28 суток при формовании конструкций с немедленной распалубкой в сравнении с бетонами, распалубка которых производилась через сутки после формования. У виброуплотненных бетонов из жесткой бетонной смеси такое снижение прочности составляет $12 \ldots 15 \%$. Приведенные данные свидетельствуют о преимуществах вибровакуумированного бетона перед виброуплотненными из жесткой бетонной смеси.
\end{abstract}

Ключевые слова: вакуумбетон, капиллярное давление, формование, немедленная распалубка, вибровакуумирование, структурная прочность.

Стаття надійшла до редакції 08.10.2020 